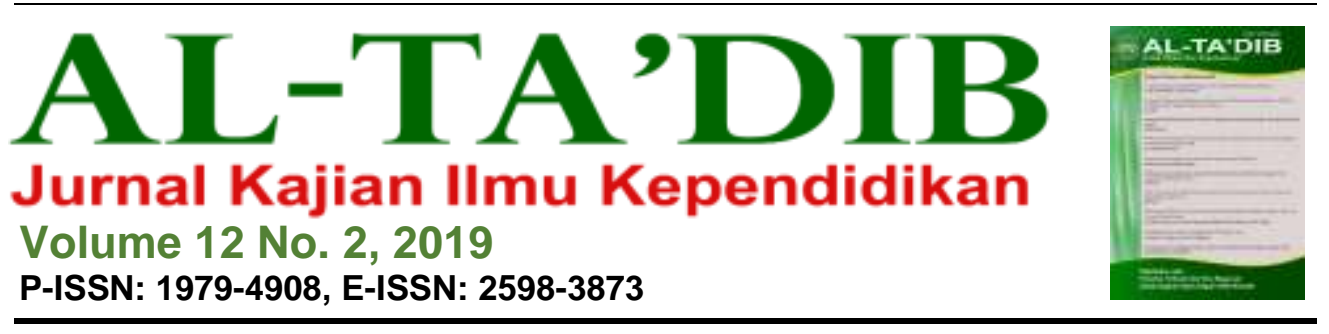

\title{
Pengaruh Metode Pembelajaran Kuantum dan Penilaian Kinerja Berbasis Rubrik Terhadap Hasil Belajar Matematika Siswa
}

\author{
La Boy ${ }^{1}$ \\ ${ }^{1}$ Institut Agama Islam Negeri Kendari, Kendari, Indonesia.E-mail: la.boy15@yahoo.co.id
}

\begin{tabular}{l} 
INFORMASI ARTIKEL \\
\hline Kata Kunci: \\
Hasil belajar; metode \\
pembelajaran; penilaian \\
kinerja berbasis rubrik \\
Cara Mensitasi: \\
Boy, L. (2019). Pengaruh \\
Metode Pembelajaran \\
Kuantum dan Penilaian \\
Kinerja Berbasis Rubrik \\
terhadap Hasil Belajar \\
Matematika Siswa. Al- \\
Tadib:Jurnal Kajian Ilmu \\
Kependidikan, 12(2), 191- \\
207. \\
DOI: \\
http://dx.doi.org/10.31332/ \\
atdbwv12i2.1163
\end{tabular}

\begin{abstract}
ABSTRAK
Penelitian eksperimen ini bertujuan mengkaji pengaruh interaksi antara metode pembelajaran dan penilaian kinerja berbasis rubrik terhadap hasil belajar matematika siswa, mengkaji rata-rata hasil belajar matematika yang diajar dengan metode pemebelajaran kuantum dan ekspository ditinjau dari penilaian kinerja berbasis rubrik analitik dan rubrik holistik. Desain penelitian ini adalah analisis varians dua jalur dengan populasi penelitian siswa kelas VII SMP Tomia. Pengambilan sampel menggunakan simple random sampling. Teknik pengambilan data menggunakan tes hasil belajar siswa. Hasil penelitian menunjukkan ada pengaruh yang signifikan antara metode pembelajaran dan penilaian kinerja berbasis rubrik terhadap hasil belajar matematika siswa. Rata-rata hasil belajar matematika siswa yang diajarkan dengan metode pembelajaran kuantum lebih tinggi daripada yang diajarkan dengan metode pembelajaran ekspositori pada kelompok siswa yang diberi penilaian kinerja berbasis rubrik analitik. Rata-rata hasil belajar matematika siswa yang diajarkan dengan metode pembelajaran kuantum lebih rendah dari pada yang diajarkan dengan metode pembelajaran ekspositori pada kelompok siswa yang diberi penilaian kinerja berbasis rubrik holistik. Rata-rata hasil belajar matematika siswa yang diberikan penilaian berbasis kinerja berbasis analitik lebih tinggi daripada rata-rata hasil belajar matematika siswa yang diberikan penilaian berbasis kinerja berbasis rubrik holistik pada kelompok siswa yang diberi metode pembelajaran kuantum.
\end{abstract}




\section{ARTICLE INFO}

Keywords:

Learning method; learning outcome; rubric-based performance assessment

How to cite:

Boy, L. (2019). Pengaruh Metode Pembelajaran Kuantum dan Penilaian Kinerja Berbasis Rubrik terhadap Hasil Belajar Matematika Siswa. AlTadib, 12(2), 191-206.

DOI:

http://dx.doi.org/10.31332/ atdbwv12i 2.1163

\section{Pendahuluan}

\begin{abstract}
This experimental research aims to examine the effect of interaction between learning methods and rubric-based performance assessment on students' mathematics learning outcomes, to review the average learning outcomes of mathematics under quantum learning and expository methods in terms of performance assessment based on analytic rubrics, and to review the average learning outcomes of mathematics under quantum and expository learning methods in terms of holistic rubric-based performance assessments. Using a two-way analysis of variance, the population of this study is grade VII students of SMP in Tomia. Using simple random sampling, data was collected by conducting student achievement test. The results of this study indicate that there is a significant influence between learning methods and rubric-based performance assessment on student mathematics learning outcomes. The average of students' learning outcomes in mathematics taught with quantum learning methods is higher than the average of those taught with expository learning methods in groups of students who are given performance evaluation based on analytic rubrics. Furthermore, the average of students' learning outcomes in mathematics taught with quantum teaching learning methods is lower than those taught with expository learning methods in groups of students who were given a holistic rubric based performance assessment. Also, the average of mathematics learning outcomes of students given analytic-based performance based assessments is higher than those who are given holistic rubric-based performance assessments on groups of students who are given quantum learning methods.
\end{abstract}

Dalam konteks pembaharuan pendidikan, ada tiga isu utama yang perlu disoroti, yaitu pembaharuan kurikulum, peningkatan kualitas pembelajaran, dan efektifitas metode pembelajaran. Kurikulum pendidikan harus komprehensif dan responsif terhadap dinamika sosial, relevan, tidak overload, dan mampu mengakomodasi keberagaman keperluan dan kemajuan teknologi. Kualitas pembelajaran harus ditingkatkan untuk meningkatkan kualitas hasil pendidikan. Secara mikro, harus ditemukan strategi atau metode pembelajaran yang efektif di kelas, yang lebih memberdayakan potensi siswa (Zarkasih \& Firdaus, 2009).

Peningkatan kualitas pembelajaran yang diselenggarakan di sekolah sangat menentukan kemajuan pendidikan suatu negara. Pembelajaran yang 
baik akan memberikan hasil belajar sesuai dengan yang diharapkan. Hal itu dapat dikaitkan dengan simpulan penelitian bahwa proses pembelajaran yang baik adalah pembelajaran yang memberikan ruang bagi peserta didik untuk berinteraksi dan bersosialisasi satu dengan yang lain (Saifulloh, Muhibbin, \& Hermanto, 2012). Paradigma pembelajaran mengalami perubahan dari yang semula pembelajaran berpusat pada guru (teacher centered) menuju pembelajaran inovatif yang berpusat pada peserta didik (student centered). Pembelajaran tersebut menempatkan peserta didik tidak hanya sebagai obyek belajar tetapi juga sebagai subyek sehingga substansi pembelajaran benarbenar dihayati.

Dalam proses belajar mengajar, guru harus memiliki metode mengajar yang bisa membuat siswa belajar secara efektif dan efisien. Salah satu langkah untuk memiliki metode belajar adalah dengan menguasai teknikteknik atau strategi penyajian mengajar yang biasa disebut dengan metode pembelajaran. Metode adalah cara yang digunakan oleh guru dalam melaksanakan kegiatan belajar mengajar di kelas sebagai upaya untuk mencapai tujuan pembelajaran yang telah ditetapkan. Sanjaya (2006) menjelaskan bahwa metode adalah cara yang digunakan untuk mengimplementasikan rencana yang sudah disusun tercapai secara optimal.

Dengan kata lain, metode merupakan langkah operasional dari strategi pembelajaran yang dipilih dalam mencapai tujuan belajar. Ketepatan penggunaan suatu metode akan menunjukkan fungsi strategi dalam kegiatan pembelajaran. Uno (2007) mengemukakan bahwa metode lebih bersifat prosedural yaitu berisi tahapan tertentu. Menurut Sudjana (2005), metode adalah pengorganisasian peserta didik didalam upaya mencapai tujuan belajar.

Pembelajaran adalah upaya membelajarkan siswa untuk belajar (Riyanto, 2014) dan upaya membuat hasil belajar dapat tercapai. Lebih lengkap menurut Chatib (2009), pembelajaran adalah proses transfer ilmu dua arah, antara guru sebagai pemberi informasi dan siswa sebagai penerima informasi. Dengan demikian pembelajaran adalah usaha yang memanfaatkan berbagai strategi, metode dan teknik guna mewujudkan tercapainya kompetensi/hasil belajar tertentu. Kegiatan pembelajaran yang diharapkan adalah kegiatan yang melibatkan siswa mempelajari sesuatu dengan cara efektif dan efisien.

Metode pembelajaran merupakan suatu cara penyampaian materi ajar yang dilakukan oleh guru terhadap siswanya di dalam kelas. Secara sederhana Chatib (2009) mengemukakan bahwa metode pembelajaran adalah bagaimana guru mengemas gaya mengajarnya agar mudah ditangkap dan dimengerti oleh siswanya. Lebih lanjut dinyatakan bahwa pendalaman tentang metode pembelajaran ini akan menghasilkan kemampuan guru membuat siswa tertarik dan berhasil dalam belajar dalam waktu yang relatif cepat. 
Metode pembelajaran didefinisikan sebagai cara yang digunakan guru untuk mencapai tujuan pembelajaran (Uno, 2007). Dick dan Carey dalam Riyanto (2014) mengatakan bahwa metode pembelajaran adalah semua komponen materi/paket pengajaran dan prosedur yang digunakan untuk membantu siswa dalam mencapai tujuan pembelajaran. Metode pembelajaran juga diartikan sebagai suatu cara atau teknik mengajar topiktopik tertentu yang disusun secara teratur dan logis (Hudoyo, 1988). Lebih lanjut dikatakan bahwa metode pembelajaran tidak hanya terbatas pada prosedur kegiatan, melainkan termasuk seluruh komponen materi atau paket pengajaran dan pola pengajaran itu sendiri (Riyanto, 2014). Metode pembelajaran memiliki dua segi yaitu interaksi antara guru dengan siswa dan interaksi siswa dengan materi yang dipelajarinya (Hudoyo, 1988).

Soedjana (2005) menyebutkan bahwa dalam satu pendekatan dapat dilakukan lebih dari satu metode dan dalam satu metode dapat digunakan lebih dari satu teknik. Dengan demikian metode dalam rangkaian sistim pembelajaran memegang peranan yang sangat penting. Keberhasilan implementasi strategi pembelajaran sangat tergantung pada cara guru menggunakan metode pembelajaran, karena suatu strategi pembelajaran hanya mungkin dapat diimplementasikan melalui penggunaan metode pembelajaran. Metode pembelajaran dikatakan efektif apabila menghasilkan sesuatu sesuai dengan tujuan yang diharapkan. Makin tinggi kekuatannya untuk menghasilkan sesuatu makin efektif metode tersebut. Sedangkan metode pembelajaran dikatakan efisien jika penerapannya dalam menghasilkan sesuatu yang diharapkan relatif menggunakan tenaga, usaha pengeluaran biaya, dan waktu yang minimum. Dengan kata lain, semakin kecil tenaga, usaha, biaya, dan waktu yang dikeluarkan maka semakin efisien metode tersebut.

Sebagaimana metode pembelajaran umumnya, metode pembelajaran kuantum (quantum teaching) juga merupakan suatu pendekatan psikologi. Metode pembelajaran kuantum dikembangkan oleh Bobbi dePorter yang terilhami dari suatu pemikiran seorang pendidik sekaligus bapak pemercepat belajar berkebangsaan Bulgaria, Dr. Georgi Lozanov, bahwa metode belajar ini sesuai dengan cara kerja otak manusia dan cara belajar manusia pada umumnya. Lozanov (dalam dePorter, Reardon, \& Singer-Nouri, 2007) mengemukakan bahwa pembelajaran kuantum yaitu pembelajaran yang segala sesuatunya berarti, setiap kata, pikiran, tindakan, dan asosiasi dan sampai sejauh mana manusia mengubah lingkungan, presentasi, dan rancangan pengajaran, sejauh itu pula proses belajar berlangsung (dePorter, dkk., 2007).

Istilah "Quantum" lebih dikenal dalam dunia ilmu fisika yang berarti interaksi yang mengubah energi menjadi cahaya. Maksudnya, dalam pembelajaran kuantum, terjadi pengubahan bermacam-macam interaksi yang 
terjadi dalam kegiatan belajar, orkestrasi bermacam-macam interaksi yang ada di dalam dan di sekitar momen belajar (dePorter dkk., 2007). Interaksiinteraksi ini meliputi unsur-unsur belajar efektif yang memengaruhi kesuksesan siswa. Interaksi-interaksi ini memfokuskan kemampuan dan bakat alamiah guru dan siswa menjadi cahaya yang berguna bagi kemajuan mereka dalam belajar secara efektif dan efisien.

Pembelajaran kuantum merupakan cara baru yang memudahkan proses belajar yang memadukan unsur seni dan pencapaian yang terarah untuk segala mata pelajaran (Wena, 2009). Pembelajaran kuantum sebagai salah satu alternatif pembaharuan pembelajaran, menyajikan petunjuk praktis dan spesifik untuk menciptakan lingkungan belajar yang efektif, bagaimana merancang pembelajaran, menyampaikan bahan pelajaran, dan bagaimana menyederhanakan proses belajar sehingga memudahkan belajar siswa (Chatib, 2009). Kurikulumnya dikembangkan secara harmonis dan berisi kombinasi tiga unsur yaitu: keterampilan akademis (academic skill), prestasi atau tantangan fisik (physical challenge), dan keterampilan hidup (life skills). Pembelajarannya berdasarkan pada landasan konteks yang menyenangkan dan situasi penuh kegembiraan.

Wena (2009) lebih lanjut mengemukakan bahwa metode pembelajaran kuantum adalah metode pembelajaran dengan menciptakan kondisi belajar yang optimal dengan pengubahan belajar yang meriah, dengan segala nuansanya, yang menyertakan segala kaitan, interaksi dan perbedaan yang memaksimalkan momen belajar serta berfokus pada hubungan dalam lingkungan kelas interaksi sebagai landasan pembelajaran.

Penilaian kinerja adalah segala bentuk asesmen yang menuntut siswa untuk melaksanakan sebuah aktivitas atau menghasilkan sebuah produk untuk mendemonstrasikan pembelajaran (Woolfolk, 2009). Penilaian kinerja menginginkan siswa untuk mendemonstrasikan bahwa mereka dapat mengerjakan tugas tertentu, seperti menulis esai, melakukan eksperimen, menginterpretasi solusi untuk suatu masalah, memainkan sebuah lagu atau menggambarkan sesuatu (Arends, 2008). Penilaian kinerja adalah suatu pendekatan dalam mengukur status siswa cara menyuruh untuk melengkapi tugas-tugas tertentu. Penilaian kinerja adalah penilaian terhadap kemampuan siswa dalam mendemonstrasikan pengetahuan (knowledge performance) dan keterampilan (skill performance) secara tertulis dalam kaitannya dengan proses dan hasil belajar matematika berdasarkan prinsip-prinsip tugas kinerja (task performance) dan kriteria penilaian (rubrik) yang telah ditetapkan.

Menurut Popham (1995), ada tiga ciri yang harus dimiliki dalam penilaian kinerja, yaitu: 1) kriteria ganda, 2) penetapan standar kualitas, dan 3) pertimbangan nilai. Kriteria ganda adalah keseluruhan aspek dari siswa harus diperhitungkan dengan menggunakan lebih dari satu kriteria. Ada beberapa alasan penggunaan penilaian kinerja, yaitu 1) ketidakpuasan 
terhadap tes obyektif, 2) pengaruh aliran psikologi kognitif, dan 3) pengaruh penggunaan tes ekspositori yang membahayakan pembelajaran (Popham, 1995).

Rubrik merupakan panduan dalam membuat keputusan penilaian, yang biasanya disajikan dalam bentuk lembaran penilaian individu yang dengan jelas menyediakan harapan, bimbingan, dan motivasi untuk penugasan (Jacobsen, Eggen, \& Kauchak, 2009). Lebih lanjut dikatakan bahwa rubrik diberikan dalam format sederhana dan jelas dengan menggunakan bahasabahasa anak yang layak. Satu rubrik berisi serangkaian deskripsi yang merujuk pada satu kriteria dan disusun dalam skala menurun. Setiap deskripsi merinci apa yang diharapkan pada level tersebut dan memfasilitasi kejelasan pemikiran (Jacobsen, dkk., 2009). Rubrik adalah alat acuan kriteria yang digunakan untuk mengevaluasi kinerja siswa sebagai standar penguasaan dan tidak bermaksud untuk membandingkan siswa. Oleh karena itu, dalam kaitannya dengan penilaian hasil belajar matematika, reliabilitas dan validitas menjadi acuan penilaian yang sangat bergantung kepada rubrik, bagaimana rubrik dikembangkan sehingga dapat mengidentifikasi hal-hal penting yang akan menjadi kriteria, serta diharapkan dapat membedakan tingkat kinerja siswa berdasarkan kriteria yang telah ditetapkan.

Matematika adalah pelajaran tentang hubungan antara kuantitaskuantitas, besaran-besaran, aturan-aturan, dan operasi-operasi secara logika dengan kuantitas-kuantitas yang tidak diketahui, namun besaran-besaran dan aturan itu bisa diedukasi. Hal ini sesuai dengan pendapat Hudoyo (1988) yang mengatakan bahwa matematika berkenaan dengan ide-ide (gagasangagasan), struktur-struktur dan hubungan-hubungan yang diukur secara logika sehingga matematika berkaitan dengan konsep-konsep abstrak. Suatu kebenaran matematika dikembangkan berdasarkan atas alasan logika dengan menggunakan pembuktian deduktif. Sedangkan Soedjadi (dalam Purwanto, 2010) berpendapat bahwa simbol-simbol didalam matematika umumnya masih kosong dari arti sehingga dapat diberi arti sesuai dengan lingkup semestanya. Agar supaya simbol itu berarti maka harus dipahami ide yang terkandung di dalam simbol tersebut. Oleh karena itu, hal terpenting adalah ide harus dipahami sebelum ide itu sendiri disimbolkan. Misalnya, simbol $(x, y)$ merupakan pasangan symbol " $x$ " dan " $y$ " yang masih kosong dari arti. Apabila konsep tersebut dipakai dalam geometri analitik bidang, dapat diartikan sebagai koordinat titik, contohnya A $(2,3)$, B $(4,7)$, titik A $(2,3)$ titik A terletak pada perpotongan garis $x=4$ dan $y=7$. Hubungan-hubungan dengan simbol-simbol dan kemudian mengaplikasikan konsep-konsep yang dihasilkan ke situasi yang nyata. 


\section{Metode Penelitian}

Penelitian ini adalah metode eksperimen. Perlakuan yang diberikan adalah penilaian kinerja berbasis rubrik analitik dan penilaian kinerja berbasis rubrik holistik. Sedangkan metode pembelajaran terdiri atas metode pembelajaran kuantum dan metode pembelajaran ekspositori. Dua metode pembelajaran ini diajarkan oleh dua orang guru mata pelajaran matematika, yaitu seorang mengajar dengan metode pembelajaran kuantum, dan seorang lagi mengajar dengan metode ekspositori.

Desain penelitian yang digunakan sebagai landasan pelaksanaan penelitian ini adalah analisis varians dua jalan (Kadir, 2010). Variabel dalam penelitian ini terdiri atas variabel bebas dan variabel terikat. Variabel bebas dalam penelitian ini adalah metode pembelajaran $\left(\mathrm{X}_{1}\right)$ dan penilaian kinerja berbasis rubrik $\left(\mathrm{X}_{2}\right)$, sedangkan variabel terikat adalah hasil belajar matematika (Y). Variabel bebas metode pembelajaran terdiri atas dua bagian, yaitu metode pembelajaran kuantum dan metode pembelajaran ekspositori. Variabel bebas penilaian kinerja berbasis rubrik juga terdiri atas dua bagian, yaitu penilaian kinerja berbasis rubrik analitik dan penilaian kinerja berbasis rubrik holistik.

Populasi dalam penelitian ini adalah seluruh siswa SMPN 1 Tomia dan SMPN 2 Tomia Kabupaten Wakatobi Provinsi Sulawesi Tenggara. Sampel pada penelitian ini diperoleh melalui tiga tahap, yaitu 1) menentukan tingkat (VII, VIII, dan IX); 2) menentukan kelas sampel; dan 3) menentukan subyek/responden. Untuk menentukan tingkat mana yang akan dipilih untuk sampel maka dilakukan cluster sampling. Cara menentukan kelas yang menjadi sampel yaitu dengan mengambil masing-masing dua kelas dari SMP Negeri 1 Tomia dan SMP Negeri 2 Tomia secara acak (Sugiyono, 2010), yaitu kelas VII. Subyek penelitian diambil masing-masing 20 siswa dari kelas sampel. Teknik pengumpulan data menggunakan tes hasil belajar yang diberikan kepada siswa.

\section{Hasil dan Pembahasan}

Dalam analisis inferensial, terdapat beberapa tahap analisis yang menjadi prasyarat untuk melakukan analisis uji hipotesis yaitu analisis uji normalitas data dan analisis uji homogenitas data. Analisis uji normalitas data dimaksudkan untuk mengetahui apakah data hasil belajar yang diperoleh berdistribusi normal atau tidak, sedangkan analisis homogenitas dimaksudkan untuk mengetahui apakah kedua kelompok data memiliki variansii yang homogeny atau tidak. 


\subsection{Uji Normalitas}

Uji normalitas dilakukan untuk mengetahui apakah sampel berasal dari populasi yang berdistribusi normal. Uji normalitas dapat dilakukan dengan menggunakan uji Lilliefors dan sebagai dasar penolakan atau penerimaan keputusan normal tidaknya distribusi data dapat ditetapkan pada taraf signifikan $\mathrm{L}_{\mathrm{t}}$ atau taraf $\alpha=0.05$. Perumusan hipotesis yang akan diuji adalah:

$\mathrm{H}_{0}$ : Sampel berasal dari populasi berdistribusi normal

$\mathrm{H}_{1}$ : Sampel berasal dari populasi berdistribusi tidak normal

Dengan ketentuan penolakan dan penerimaan hipotesis sebagai berikut:

$\mathrm{H}_{0}$ diterima apabila $\mathrm{L}_{\text {hitung }}<\mathrm{L}_{\mathrm{t}}$ dan

$\mathrm{H}_{1}$ ditolak apabila $\mathrm{L}_{\text {hitung }}>\mathrm{L}_{\mathrm{t}}$.

Tabel 1 Rekapitulasi hasil uji normalitas sampel dengan uji Lilliefors pada taraf $\alpha=$ 0.05 .

\begin{tabular}{ccccc}
\hline Kelompok & $\begin{array}{c}\text { Jumlah } \\
\text { Sampel }\end{array}$ & $\mathbf{L}_{\text {hitung }}\left(\mathbf{L}_{\mathbf{o}}\right)$ & $\begin{array}{c}\mathbf{L}_{\text {tabel }} \\
\left(\mathbf{L}_{\mathbf{t} \mathbf{a}=\mathbf{0}, \mathbf{0}}\right)\end{array}$ & Kesimpulan \\
\hline $\mathrm{A}_{1}$ & 40 & 0,086 & 0,137 & Normal \\
$\mathrm{A}_{2}$ & 40 & 0,087 & 0,137 & Normal \\
$\mathrm{B}_{1}$ & 40 & 0,082 & 0,137 & Normal \\
$\mathrm{B}_{2}$ & 40 & 0,080 & 0,137 & Normal \\
$\mathrm{A}_{1} \mathrm{~B}_{1}$ & 20 & 0,067 & 0,194 & Normal \\
$\mathrm{A}_{1} \mathrm{~B}_{2}$ & 20 & 0,093 & 0,194 & Normal \\
$\mathrm{A}_{2} \mathrm{~B}_{1}$ & 20 & 0,105 & 0,194 & Normal \\
$\mathrm{A}_{2} \mathrm{~B}_{2}$ & 20 & 0,132 & 0,194 & Normal \\
\hline $\mathrm{Ke}^{2}$ & & & & \\
\hline
\end{tabular}

Keterangan:

$\mathrm{L}_{0} \quad=$ Nilai hitung Lilliefors

$\mathrm{L}_{\mathrm{t}} \quad=$ Nilai kritis Lilliefors

Berdasarkan hasil perhitungan normalisasi pada tabel rekapitulasi di atas diperoleh untuk jumlah sampel (n) sebesar 40 responden pada taraf signifikan $\alpha=$ 0,05 maka nilai kritis $L_{t}$ sebesar 0,137. Pada kelompok siswa yang diberi metode pembelajaran kuantum diperoleh $\mathrm{L}_{0}=0.086$, lebih kecil dari $\mathrm{L}_{\mathrm{t}}$ sehingga $\mathrm{H}_{0}$ diterima. Dapat disimpulkan bahwa data hasil belajar kelompok siswa yang diberi pembelajaran kuantum berasal dari populasi yang berdistribusi normal.

Pada kelompok siswa yang diberi metode pembelajaran ekspositori adalah $\mathrm{L}_{0}=0.087$ lebih kecil dari $\mathrm{L}_{\mathrm{t}}$ sehingga $\mathrm{H}_{0}$ diterima. Dapat disimpulkan bahwa data hasil belajar kelompok siswa yang diberi metode 
pembelajaran ekspositori tersebut berasal dari populasi yang terdistribusi normal. Pada kelompok siswa yang diberi penilaian kinerja berbasis rubrik analitik adalah $\mathrm{L}_{0}=0,082$, lebih kecil dari $\mathrm{L}_{\mathrm{t}}$ sehingga $\mathrm{H}_{0}$ diterima. Dapat disimpulkan bahwa data hasil belajar kelompok siswa yang diberi penilaian kinerja berbasis rubrik analitik tersebut berasal dari populasi yang terdistribusi normal. Dan pada kelompok siswa yang diberi penilaian kinerja berbasis rubrik analitik adalah $\mathrm{L}_{0}=0,080$ lebih kecil dari $\mathrm{L}_{\mathrm{t}}$ sehingga $\mathrm{H}_{0}$ diterima. Juga dapat disimpulkan bahwa data hasil belajar kelompok siswa yang diberi penilaian kinerja berbasis rubrik analitik tersebut berasal dari populasi yang terdistribusi normal.

Selanjutnya untuk jumlah sampel (n) sebesar 20 responden pada taraf signifikan $\alpha=0,05$ maka nilai kritis $\mathrm{L}_{\mathrm{t}}=0,194$. Pada kelompok siswa yang diajarkan dengan pembelajaran kuantum dan diberi penilaian kinerja berbasis rubrik analitik adalah $\mathrm{L}_{0}=0,067$ lebih kecil daripada $\mathrm{L}_{\mathrm{t}}$ sehingga $\mathrm{H}_{0}$ diterima. Dapat disimpulkan bahwa data hasil belajar kelompok siswa yang diajarkan dengan pembelajaran kuantum dan diberi penilaian kinerja berbasis rubrik analitik tersebut berasal dari populasi yang terdistribusi normal. Pada kelompok siswa yang diajarkan dengan metode ekspositori dan diberi penilaian kinerja berbasis rubrik analitik adalah $\mathrm{L}_{0}=0,093$ lebih kecil daripada $\mathrm{L}_{t}$ sehingga $\mathrm{H}_{0}$ diterima. Dapat disimpulkan bahwa data hasil belajar kelompok siswa yang diajarkan dengan metode ekspositori dan diberi penilaian kinerja berbasis rubrik analitik tersebut berasal dari populasi yang terdistribusi normal.

Pada kelompok siswa yang diajarkan dengan pembelajaran kuantum dengan yang diberi penilaian kinerja berbasis rubrik holistik adalah $\mathrm{L}_{0}=$ 0,093 lebih kecil daripada $\mathrm{L}_{t}$ sehingga $\mathrm{H}_{0}$ diterima. Dapat disimpulkan bahwa data hasil belajar kelompok siswa yang diajarkan dengan pembelajaran kuantum dengan yang diberi penilaian kinerja berbasis rubrik holistic tersebut berasal dari populasi yang terdistribusi normal. Pada kelompok siswa yang diberi metode pembelajaran ekspositori dan diberi penilaian kinerja berbasis hoistik sebesar L0 $=0.132$ lebih kecil daripada Lt sehingga H0 diterima. Dapat disimpulkan bahwa data hasil belajar kelompok siswa yang diberi metode pembelajaran ekspositori dan penilaian konerja berbasis rubrik holistik berasal dari populasi yang terdistribusi normal.

\subsection{Uji Homogenitas}

Uji homogenitas dilakukan untuk melihat apakah data penelitian berasal dari variansi yang sama (homogen). Uji homogenitas varians data hasil belajar matematika siswa pada dua kelompok metode pembelajaran (Kelompok A1 dan A2) dan pada dua kelompok penilaian kinerja berbasis rubrik (kelompok B1 dan B2) dengan uji-F. Hasil perhitungan kelompok 
data $A_{1}$ dan $A_{2}$ diperoleh $F_{\text {hitung }}=1,42$ dan kelompok data $B_{1}$ dan $B_{2}$ diperoleh $F_{\text {hitung }}=1,20 . F_{\text {hitung }}$ kedua kelompok ini lebih kecil dari $\mathrm{F}_{\text {tabel }(0,01 ; 39 ; 39)}=2,11 \quad \mathrm{~F}_{\text {tabel }(0,05 ; 39 ; 39)}=1,69$. Dengan demikian baik kelompok data $\mathrm{A}_{1}$ dan $\mathrm{A}_{2}$ maupun kelompok data $\mathrm{B}_{1}$ dan $\mathrm{B}_{2}$ homogen.

Uji homogenitas empat kelompok sel rancangan eksperimen $\left(\mathrm{A}_{1} \mathrm{~B}_{1}\right.$, $\mathrm{A}_{1} \mathrm{~B}_{2}, \quad \mathrm{~A}_{2} \mathrm{~B}_{1}$, dan $\mathrm{A}_{2} \mathrm{~B}_{2}$ ), dilakukan dengan pengujian homogenitas menggunakan Uji Bartlett. Kriteria pengujiannya, yakni:

$\mathrm{H}_{0}: \sigma_{1}^{2}=\sigma_{2}^{2}=\sigma_{3}^{2}=\sigma_{4}^{2}$

$\mathrm{H}_{1}$ : Salah satu tanda berbeda

Dasar dalam pengambilan keputusan sebagai berikut:

$\mathrm{H}_{0}$ diterima apabila $\chi_{\text {hitung }}^{2} \chi_{\text {tabel }}^{2}$ dan

$\mathrm{H}_{1}$ ditolak apabila $\chi^{2}$ hitung $>\chi^{2}$ tabel . dengan taraf signifikansi $\alpha=0,05$

Tabel 2 Rangkuman hasil uji homogenitas varian pada kelompok penelitian dengan taraf signifikansi $\alpha=0,05$

\begin{tabular}{lcccccc}
\hline Sampel & $\mathrm{dk}$ & $1 / \mathrm{dk}$ & $\mathrm{s}_{\mathrm{i}}{ }^{2}$ & $\log \mathrm{s}_{\mathrm{i}}{ }^{2}$ & $\mathrm{dk} \mathrm{s}^{2}$ & $(\mathrm{dk}) \log \mathrm{si}^{2}$ \\
\hline $\mathrm{A}_{1} \mathrm{~B}_{1}$ & 19 & 0,053 & 34,905 & 1,543 & 663,20 & 29,31 \\
$\mathrm{~A}_{1} \mathrm{~B}_{2}$ & 19 & 0,053 & 26,171 & 1,418 & 497,26 & 26,94 \\
$\mathrm{~A}_{2} \mathrm{~B}_{1}$ & 19 & 0,053 & 51,116 & 1,709 & 971,20 & 32,46 \\
$\mathrm{~A}_{2} \mathrm{~B}_{2}$ & 19 & 0,053 & 36,579 & 1,563 & 695,00 & 29,70 \\
Jumlah & 76 & 0,211 & 148,771 & 6,233 & $2.826,66$ & 118,42 \\
\hline
\end{tabular}

Keterangan:

$\mathrm{A}_{1} \mathrm{~B}_{1}=$ Kelompok Siswa yang diajarkan dengan pembelajaran kuantum dan diberi penilaian kinerja berbasis analitik

$\mathrm{A}_{1} \mathrm{~B}_{2}=$ Kelompok Siswa yang diajarkan dengan pembelajaran kuantum dan diberi penilaian kinerja berbasis holistik

$\mathrm{A}_{2} \mathrm{~B}_{1}=$ Kelompok Siswa yang diajarkan dengan metode pembelajaran ekspositori dan diberi penilaian kinerja berbasis analitik

$\mathrm{A}_{2} \mathrm{~B}_{2}=$ Kelompok Siswa yang diajarkan dengan metode pembelajaran ekspositori dan diberi penilaian kinerja berbasis holistik

Berdasarkan perhitungan diperoleh nilai $\chi^{2}$ hitung $=2,049$, sedangkan $\chi_{\text {tabel }}^{2}$ untuk taraf signifikansi $\alpha=0,05$ dengan jumlah kelompok $4-1=3$ adalah 7,815. Dengan demikian $\chi^{2}$ hitung $<\chi^{2}$ tabel( $(0,05 ; 3)$ sehingga $\mathrm{H}_{\mathrm{o}}$ diterima, berarti variansi dari keempat kelompok $\left(\mathrm{A}_{1} \mathrm{~B}_{1}, \mathrm{~A}_{1} \mathrm{~B}_{2}, \mathrm{~A}_{2} \mathrm{~B}_{1}, \mathrm{~A}_{2} \mathrm{~B}_{2}\right)$ adalah homogen. 


\subsection{Uji Hipotesis}

Pengujian hipotesis dalam penelitian ini dilakukan dengan menggunakan analisis varian (ANAVA) dua jalur. Analisis varian dua jalur digunakan untuk menguji pengaruh utama (main effect), interaksi (interaction effect) dan pengaruh sederhana (simple effect) antara metode pembelajaran dan penilaian kinerja berbasis rubrik. Selanjutnya jika hasil perhitungan tersebut menunjukkan adanya interaksi antara metode pembelajaran dan penilaian kinerja berbasis rubrik terhadap hasil belajar, maka dilanjutkan perhitungan dengan formulasi uji t-Dunnet (Kadir, 2010).

Berdasarkan uraian data tersebut, maka dilakukan perhitungan secara manual, dengan menggunakan ANAVA diperoleh hasil analisis seperti pada tabel 3 di bawah ini.

Tabel 3 Hasil analisis varians menggunakan ANAVA dua jalur

\begin{tabular}{lcccccc}
\hline \multirow{2}{*}{ Sumber Varians } & \multirow{2}{*}{$\mathrm{JK}$} & $\mathrm{db}$ & $\mathrm{RJK}$ & $\mathrm{F}_{\text {hitung }}$ & $\alpha=0,05$ & $\alpha=0,01$ \\
\hline Antar A & 168,2 & 1 & 168,2 & $4,38^{*}$ & 3,97 & 6,98 \\
Antar B & 156,8 & 1 & 156,8 & $4,09^{*}$ & & \\
Interaksi AB & 2080,8 & 1 & 2080,8 & $54,24^{* *}$ & & \\
Dalam & 3069,2 & 76 & 38,37 & & & \\
Total (T) & 5475 & 80 & & & & \\
\hline
\end{tabular}

Keterangan:

$* * \quad=$ Sangat signifikan jika digunakan $\alpha=0,05$

$\mathrm{dk}=$ Derajat kebebasan

$\mathrm{JK}=$ Jumlah kuadrat

RJK = Rerata jumlah kuadrat

Kriteria pengujian yang digunakan yaitu:

$\mathrm{H}_{0}$ diterima apabila $\mathrm{F}_{\text {hitung }}<\mathrm{F}_{\text {tabel }}$,

$\mathrm{H}_{1}$ diterima apabila $\mathrm{F}_{\text {hitung }}>\mathrm{F}_{\text {tabel }}$.

Berdasarkan hasil analisis varians (ANAVA) dua jalur pada Tabel 3, hasil perhitungan hipotesis 1 dengan formulasi ANAVA dua jalur menunjukkan bahwa $F_{\text {hitung }}=54,24>\mathrm{F}_{\text {tabel }}=3,95$ pada taraf signifikansi $\alpha=$ 0,05. Karena $F_{\text {hitung }}>F_{\text {tabel }}$, maka hipotesis nol $\left(\mathrm{H}_{0}\right)$ ditolak. Artinya, terdapat efek interaksi antara metode pembelajaran dan penilaian kinerja berbasis rubrik secara signifikan. Berdasarkan perhitungan diperoleh interaksinya sebesar 39,96\% antara metode pembelajaran dan penilaian kinerja berbasis rubrik terhadap hasil belajar matematika siswa. Besarnya interaksi ini 
nampak dengan jelas pada Gambar 1 dan dapat dijelaskan sebagai berikut ini:

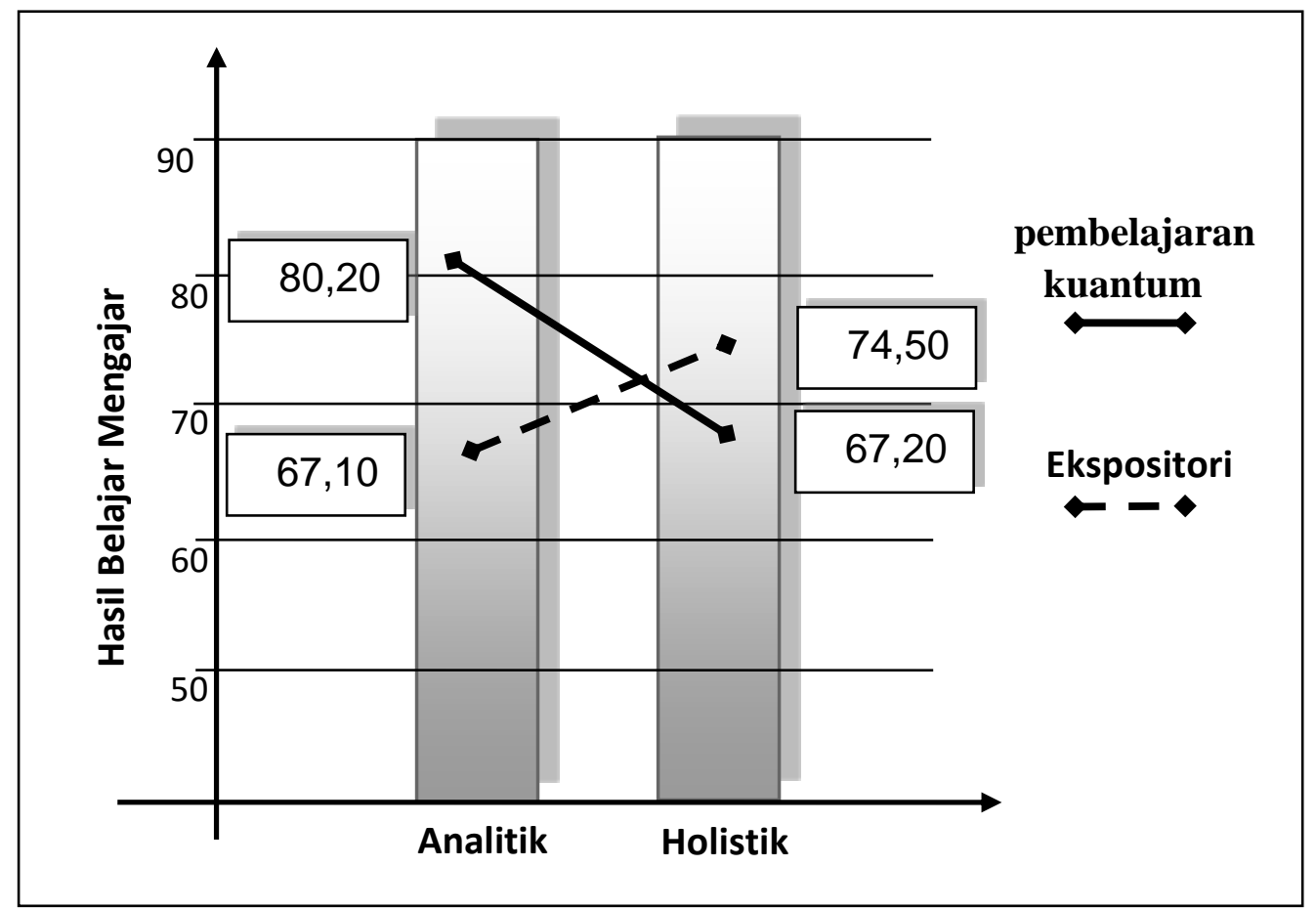

Gambar 1 Pengaruh interaksi metode pembelajaran dan penilaian kinerja berbasis rubrik

Dari Gambar 1 di atas dapat dikatakan bahwa pada kelompok siswa yang diberi pembelajaran kuantum dan diberi penilaian kinerja berbasis rubrik analitik $\left(\mathrm{A}_{1} \mathrm{~B}_{1}\right)$ lebih tinggi dibanding dengan kelompok siswa yang diberi metode pembelajaran ekspositori dan diberi penilaian kinerja berbasis holistik $\left(\mathrm{A}_{2} \mathrm{~B}_{2}\right)$. Atau sebaliknya pada kelompok siswa yang diberi metode pembelajaran ekspositori dan penilaian kinerja berbasis rubrik analitik (A2B1) lebih kecil dari kelompok siswa yang diberi pembelajaran kuantum dan penilaian kinerja berbasis rubrik holistik $\left(\mathrm{A}_{2} \mathrm{~B}_{2}\right)$.

Perpotongan kedua garis tersebut menunjukkan bahwa terdapat interaksi antara dua variabel bebas terhadap variabel terikat. Interaksi yang dimaksud adalah terdapat pengaruh metode pembelajaran terhadap hasil belajar matematika tergantung dari penilaian kinerja berbasis rubrik yang digunakan, atau sebaliknya. Konsekuensi dari interaksi secara signifikan ini maka perlu dilakukan uji perbedaan rata-rata untuk mengetahui perbedaan rata-rata pada level $A_{1}$ dan $A_{2}$ serta $B_{1}$ dan $B_{2}$ yang dalam penelitian ini menggunakan uji t-Dunnet, untuk mengetahui hipotesis yang diajukan. 
Tabel 4 Hasil perhitungan lanjutan dengen formulasi uji t-Dunnet

\begin{tabular}{ccccc}
\hline $\begin{array}{c}\text { Kelompok } \\
\text { Perbandingan }\end{array}$ & $\mathrm{n}$ & $\mathrm{db}(\mathrm{k}, \mathrm{n})$ & $\mathrm{t}_{\text {hitung }}$ & $\mathrm{t}_{\text {tabel }(\alpha=0.05)}$ \\
\hline $\mathrm{t}\left(\mathrm{A}_{1} \mathrm{~B}_{1}-\mathrm{A}_{2} \mathrm{~B}_{1}\right)$ & 20 & 36 & $6,64^{* * *}$ & 1,99 \\
$\mathrm{t}\left(\mathrm{A}_{1} \mathrm{~B}_{2}-\mathrm{A}_{2} \mathrm{~B}_{2}\right)$ & 20 & & $3,78^{* *}$ & \\
\hline
\end{tabular}

Keterangan:

** = sangat signifikan jika menggunakan $\alpha=0,05$

Hasil penelitian ini sejalan dengan penelitian Wahyuni, Candiasa, dan Suarni (2014) yang menemukan bahwa terdapat pengaruh pencapaian hasil belajar matematika kelompok siswa yang belajar dengan model pembelajaran kuantum berorientasi pembelajaran matematika realistik lebih tinggi dibandingkan dengan kelompok siswa yang pembelajarannya menggunakan model pembelajaran konvensional. Dengan kata lain, bahwa model pembelajaran kuantum berorientasi pendidikan matematika realistik lebih unggul dibandingkan dengan model pembelajaran konvensional, dalam pencapaian hasil belajar matematika.

Berdasarkan perhitungan dengan menggunakan uji t-Dunnet pada Tabel 4 di atas untuk hipotesis 2 diperoleh nilai $\mathrm{t}_{\text {hitung }}=6,64>\mathrm{t}_{\text {tabel }}=1,99$ pada taraf signifikansi $\quad \alpha=0,05$. Karena thitung $>t_{\text {tabel }}$ maka dapat disimpulkan bahwa Hipotesis nol $\left(\mathrm{H}_{0}\right)$ ditolak, artinya rata-rata hasil belajar matematika siswa yang diajarkan dengan pembelajaran kuantum lebih tinggi dari pada rata-rata hasil belajar matematika siswa yang diajarkan dengan metode pembelajaran ekspositori pada kelompok siswa yang diberi penilaian kinerja berbasis rubrik analitik.

Untuk hipotesis 3 berdasarkan Tabel 4 perhitungan dengan menggunakan uji t-Dunnet diperoleh nilai $\mathrm{t}_{\text {hitung }}=3,78<\mathrm{t}_{\text {tabel }}=1,99$ pada taraf signifikansi $\alpha=0,05$. Karena $t_{\text {hitung }}<t_{\text {tabel }}$ maka dapat disimpulkan bahwa Hipotesis nol $\left(\mathrm{H}_{0}\right)$ ditolak, artinya rata-rata hasil belajar matematika siswa yang diajarkan dengan pembelajaran kuantum lebih rendah dari pada rata-rata hasil belajar matematika siswa yang diajarkan dengan metode pembelajaran ekspositori pada kelompok siswa yang diberi penilaian kinerja berbasis rubrik holistik.

Untuk hipotesis 4 berdasarkan Tabel 4 perhitungan dengan menggunakan uji t-Dunnet diperoleh nilai $\mathrm{t}_{\text {hitung }}=6,27>\mathrm{t}_{\text {tabel }}=1,99$ pada taraf signifikansi $\alpha=0,05$. Karena $t_{\text {hitung }}>t_{\text {tabel }}$ maka dapat disimpulkan bahwa Hipotesis nol $\left(\mathrm{H}_{0}\right)$ ditolak, artinya rata-rata hasil belajar matematika siswa yang diberikan dengan penilaian kinerja berbasis rubrik analitik lebih tinggi dari pada rata-rata hasil belajar matematika siswa yang diberikan 
penilaian kinerja berbasis rubrik holistik pada kelompok siswa yang diajarkan dengan metode kuantum.

Hasil penelitian ini sejalan dengan penelitian Wahyuni, dkk (2014) yang menemukan bahwa terdapat perbedaan hasil belajar yang signifikan antara kelompok siswa yang menggunakan asesmen autentik dan kelompok siswa yang menggunakan asesmen konvensional. Pencapaian hasil belajar matematika kelompok siswa yang diberikan asesmen autentik lebih tinggi dibandingkan dengan kelompok siswa yang diberikan asesmen konvensional. Dengan kata lain, bahwa asesmen autentik lebih unggul dibandingkan dengan asesmen konvensional dalam pencapaian hasil belajar matematika.

\subsection{Pembahasan}

Hasil belajar matematika siswa dipengaruh oleh metode pembelajaran dan penilaian kinerja berbasis rubrik. Penilaian kinerja rubrik analitik adalah penilaian kinerja secara detail, analitik, sehingga dalam satu soal dapat terdiri atas beberapa skor. Untuk menentukan nilai seorang siswa harus menjumlahkan skor dari beberapa dimensi, kemudian dikonversi ke nilai. Mengingat penilaian kinerja rubrik analitik yang menuntut kinerja yang mendetail dan tiga dimensi di atas maka siswa harus mengekspresikan semua kemampuan dalam menyelesaikan suatu soal atau tugas.

Tujuan guru melakukan penilaian kinerja dalam proses pembelajaran matematika adalah untuk mengetahui tingkat keberhasilan belajar siswa dan efisiensi suatu pembelajaran matematika itu sendiri dengan mengacu kepada standar kompetensi dan beberapa kompetensi dasar yang ingin dicapai pada pokok bahasan tertentu melalui indikator-indikator berikut sebagai berikut. Pertama, pemahaman konsep, bahwa siswa dilatih mampu mendefenisikan konsep permasalahan matematika, mengidentifikasi dan memberi contoh atau bukan contoh dari konsep tersebut. Kedua, prosedur, bahwa siswa dilatih mampu mengenali prosedur atau proses menghitung yang benar dan tidak benar. Ketiga, komunikasi, bahwa siswa dilatih mampu menyatakan dan menafsirkan gagasan matematika secara lisan, tertulis, atau mendemonstrasikannya. Keempat, penalaran, bahwa siswa dilatih mampu memberikan alasan induktif dan desuktif sederhana. Kelima, pemecahan masalah, bahwa siswa dilatih mampu memahami masalah, memilih strategi penyelesaian, serta mampu menyelesaikan masalah matematika tersebut. Tuntutan ini yang perlu diperhatikan sehingga jika penilaian kinerja berbasis

rubrik analitik dapat diterapkan oleh guru di dalam kelas dengan baik maka diharapkan dapat meningkatkan hasil belajar matematika siswa dibandingkan dengan penilaian kinerja berbasis rubrik holistik. 
Terkait penilaian kinerja berbasis rubrik holistic, ia tidak menuntut kinerja siswa lebih jauh. Penilaian kinerja berbasis rubrik holistik menilai secara umum dan sedikit sekali hasil kinerja yang dicapai. Penilaian ini cenderung digunakan untuk penilaian kinerja yang cepat dan tidak mendalam. Dengan demikian, penilaian ini tidak menekankan kepada siswa akan jawaban yang lengkap dan mendalam. Mengingat pada penilaian ini tidak ada tantangan yang berarti, upaya siswa juga untuk belajar kurang nampak. Oleh karena itu, hasil belajar matematika siswa kelompok yang diberi penilaian kinerja berbasis rubrik analitik akan lebih efektif dibandingkan dengan hasil belajar matematika siswa kelompok yang diberi penilaian kinerja berbasis rubrik holistik.

\section{Kesimpulan}

Berdasarkan hasil analisis dan pembahasan dapat disimpulkan bahwa ada pengaruh yang signifikan antara metode pembelajaran dan penilaian kinerja berbasis rubrik terhadap hasil belajar matematika siswa. Selain itu, rata-rata hasil belajar matematika siswa yang diajarkan dengan metode pembelajaran kuantum lebih tinggi dari pada rata-rata hasil belajar matematika siswa yang diajarkan dengan metode pembelajaran ekspositori pada kelompok siswa yang diberi penilaian kinerja berbasis rubrik analitik. Penelitian ini juga menemukan bahwa rata-rata hasil belajar matematika siswa yang diajarkan dengan pembelajaran kuantum lebih rendah dari pada rata-rata hasil belajar matematika siswa yang diajarkan dengan metode pembelajaran ekspositori pada kelompok siswa yang diberi penilaian kinerja berbasis rubrik holistik. Lalu, rata-rata hasil belajar matematika siswa yang diberikan dengan penilaian kinerja berbasi rubrik analitik lebih tinggi dari pada rata-rata hasil belajar matematika siswa yang diberikan penilaian kinerja berbasis rubrik holistik pada kelompok siswa yang diajarkan dengan metode kuantum.

\section{Daftar Pustaka}

Arends, R. I. (2008). Learning to teach. (H. Prajitno \& S. Mulyantini, Pnjmh.). Yogyakarta: Pustaka Pelajar.

Chatib, M. (2009). Sekolahnya manusia. Jakarta: Kaifa.

Hudoyo, H. (1988). Teori belajar mengajar matematika. Jakarta: P2LPTK Depdikbud. 
Jacobsen, D. A., Eggen, P., \& Kauchak, D. (2009). Methods for teaching. (A. Fawaid \& K. Anam, Pnjmh.). Jakarta: Pustaka Pelajar.

Kadir. (2010). Statistika untuk penelitian ilmu-ilmu sosial. Jakarta: Rosemata Sampurna.

Popham, W. J. (1995). Classroom assessment: What teacher to know. Boston: Allyn \& Bacon.

dePorter, B., Reardon, M., \& Singer-Nourie, S. (2007). Quantum teaching. (A. Nilandari, Pnjmh). Jakarta: Kaifa.

Purwanto, E. (2010). Apa hakekat matematika. $\mathrm{http} / / /$ smansatase.sch.id/index.php?option=com_content\&view=article $\& \mathrm{id}=72:$ hakmat $\&$ catid=57:artpend\&Itemid=80 diakses，06/07/ 2010 03:03.

Riyanto, H. Y. (2014). Paradigma baru pembelajaran: Sebagai referensi bagi guru/pendidik dalam implementasi pembelajaran yang efektif dan berkualitas. Jakarta: Prenada Media.

Saifulloh, M., Muhibbin, Z., \& Hermanto. (2012). Strategi peningkatan mutu pendidikan di sekolah. Jurnal Sosial Humaniora, 5(2), 206-218.

Sanjaya, W. (2006). Strategi pembelajaran berorientasi standar proses pendidikan. Jakarta: Kencana.

Sudjana, D. (2005). Metode dan teknik pembelajaran parsipatif. Bandung: Falah Production.

Sugiyono. (2010). Metode penelitian pendidikan pendekatan kuantitatif, kualitatif, dan $R \& D$. Bandung: CV Alfabeta.

Uno, H. B. (2007). Model pembelajaran: Menciptakan proses belajar menagajr yang kreatif dan efektif. Jakarta: Bumi Aksara.

Van De Walle, J. A. (2007). Matematika sekolah dasar. Pengembangan pengajaran. (Soyono, Pnjmh). Jakarta: Erlangga.

Wahyuni, A. A. I. A., Candiasa, I. M., Kom, M. I., \& Suarni, N. K. (2014). Pengaruh model pembelajaran kuantum berorientasi PMRI dan asesmen autentik terhadap hasil belajar matematika siswa kelas VIII 
SMP Negeri 1 Payangan. Journal Penelitian dan Evaluasi Pendidikan Indonesia, 4, 1-10.

Wena, M. (2009). Strategi pembelajaran inovasi kontemporer. Jakarta: Bumi Aksara.

Woolfolk, A. (2009). Educational psychology. (P. Soetjipto, dkk, Pnjmh). Jakarta: Pustaka Pelajar.

Zarkasih, \& Firdaus, M. (2009). Belajar cepat dengan diskusi. Surabaya: Indah. 